\title{
DISTINGUISHING BETWEEN PRINCIPALS AND ACCESSORIES AT THE ICC - ANOTHER ASSESSMENT OF CONTROL THEORY
}

Doc. dr. sc. Maja Munivrana Vajda *

UDK: 343.121:341.4

Izvorni znanstveni rad

Primljeno: listopad 2014.

Rather than ending the discussion, the first judgment of the ICC in the Lubanga case and its endorsement of the 'control of the crime' theory seem to have opened a Pandora's Box of dissonant approaches to modes of liability before the ICC. Both practitioners and scholars have engaged in heated debates on the correct interpretation of Article 25(3) of the Rome Statute. Critics of control theory rightly point out that this theory cannot simply be deduced from the wording of the Statute itself, and that it is not the only plausible theory. Yet, arguing that the 'plain text' of Article 25(3) provides a clear-cut, straightforward insight into the content and scope of each particular mode of liability seems somewhat naive. The wording of Article 25(3) is vague and leaves the door open to different views, as demonstrated in the wealth of recent related literature. Moreover, judicial interpretation is an inherent part of the application of law and cannot be reduced to mere textual interpretation. Bearing that in mind, this paper provides a line of arguments that speak in favour of control theory. It is suggested that, while different interpretations remain possible, further endorsement of control theory would add to the ICC's internal consistency and the development of an accessible and predictable body of law applicable before that court.

Keywords: modes of liability, principals, accessories, control theory, hierarchy of blameworthiness, International Criminal Court

Maja Munivrana Vajda, Ph. D., Assistant Professor, Faculty of Law, University of Zagreb, Trg maršala Tita 14, Zagreb. This paper is dedicated to Prof. Emeritus Željko Horvatić, whose scholarly interests have included the topic of individual criminal responsibility in international criminal law, and in particular joint criminal enterprise. See D. Derenčinović, Ž. Horvatić, I. Bojanić, D. Krapac \& M. Seršić. Theory of joint criminal enterprise and international criminal law - challenges and controversies, 2011. The paper is also written as a part of the Faculty of Law, University of Zagreb, research project. 


\section{INSTEAD OF AN INTRODUCTION: A SHORT OVERVIEW OF DISSONANT VOICES ON MODES OF LIABILITY}

From the outset, the ICC made it clear that when it came to modes of liability it would not follow the well-established path taken by its predecessors, ad hoc tribunals and, in particular, the ICTY. In its early decisions, the Court manifestly rejected the (in)famous JCE theory ${ }^{1}$, and the dominant common law approach to perpetration liability. The ICC's relatively consistent hierarchical reading of the modes of liability, coupled with its strong reliance on control theory, originally embedded in the German doctrine, has divided the legal profession by attracting both appraisal and fierce criticism. While some authors dismiss only the 'control of the crime' approach ${ }^{2}$, others reject the differential approach from the outset and advocate the unitary approach. ${ }^{3}$

For a while it seemed that the critics remained 'on the outside', unable to reshape the ICC's early jurisprudence on co-perpetration and participation. However, concerns about the 'correct' interpretation of the modes of liability under Article 25(3)(a) have lately been raised even within the Court itself. In his, by now renowned and meticulously analysed ${ }^{4}$, separate opinion attached to the Lubanga Trial Chamber Judgment, Judge Fulford disagreed both with the Chamber's premise that Article 25(3) distinguishes between principal and accessorial liability, and with the application of the 'control of the crime' the-

1 Due to the malleability of the concept of joint criminal enterprise, its acronym JCE has ironically been interpreted to mean 'just convict everyone'. See, e.g., M. E. Badar, “Just Convict Everyone” - Joint Perpetration from Tadić to Stakić and Back Again’, 2006 International Criminal Law Review, no. 6, pp. 293-302. The term was first used by W. Schabas, The International Criminal Court: A Commentary on the Rome Statute, 2010.

2 Comp. L. Yanev \& T. Kooijmans, 'Divided Minds in the Lubanga trial Judgment: A Case against the Joint Control Theory', 2013 International Criminal Law Review, no. 13, pp. 789-828 and E. van Sliedregt, 'The Curious Case of International Criminal Liability', 2012 Journal of International Criminal Justice, no. 10, pp. 1171-1188, arguing that this theory is a product of judicial creativity, p. 1184.

3 E.g., J. G. Stewart, 'The End of 'Modes of Liability' for International Crimes', 2012 Leiden Journal of International Law, no. 25, pp. 165-219.

4 See, e.g., K. J. Heller, 'Lubanga Decision Roundtable: More on Co-Perpetration', <http://opiniojuris.org/2012/03/16/lubanga-decision-roundtable-more-on-coperpetration/>, (last visited 10 February 2014) and K. Ambos, 'The first judgment of the International Criminal Court (Prosecutor v. Lubanga): A comprehensive analysis of the legal issues', 2012 International Criminal Law Review, no. 12, pp. 141-150. 
ory. ${ }^{5}$ He further argued in favour of 'a plain text reading of Article 25(3)(a) of the Statute' whereby, in his view, co-perpetration (only) requires the involvement of at least two individuals, coordination between those who commit the offence, a contribution to the crime, either direct or indirect, which must simply be causally linked to the crime, intent and knowledge. ${ }^{6}$ Judge Fulford's concerns were echoed in the subsequent concurring opinion of Judge Van den Wyngaert in the Ngudjolo decision of acquittal. Judge Van den Wyngaert endorsed the 'ordinary meaning of Article 25(3)' approach and, like Judge Fulford, found the 'control of the crime' theory to be inconsistent with it. In particular, she rejected control theory's treatment of the common plan as an objective element, the idea that for joint perpetration it suffices that an accused only makes a contribution to a broadly defined common plan and not the crime itself, as well as the requirement of an 'essential' contribution. She further held that Article 25(3) did not create a hierarchy of blameworthiness nor did it allow joint perpetration and indirect perpetration to be combined as 'indirect co-perpetration'.?

These two separate, yet concurring opinions have led other judges to assert that the interpretation of Article 25(3) is "far from being uncontentious or settled". ${ }^{8}$ While that may be the case, after scrutinizing the hierarchical structure of Article 25(3) as well as the hitherto dominant 'control of the crime' paradigm, this article argues that both should be confirmed by the Appeal Chamber and continued to be applied by the ICC. The interpretation of particular elements of certain modes of liability may need further clarification and fine-tuning, but that does not mean that control theory itself should be wholly rejected.

5 Prosecutor $v$ Thomas Lubanga Dyilo, Judgment pursuant to Art. 74 of the Statute. Separate opinion of Judge Adrian Fulford, Case No. ICC-01/04-01/06-2842, T. Ch. I, 14 March 2012 (hereinafter: Separate opinion of Judge Fulford), paras. 6-8.

6 Ibid., para. 17.

7 Prosecutor v Mathieu Ngudjolo Chui, Concurring opinion of Judge Christine Van den Wyngaert, Judgment pursuant to Art. 74 of the Statute, Case No. ICC-01/0402/12-4, T. Ch. II, 18 December 2012 (hereinafter: Concurring opinion of Judge Van den Wyngaert), paras. 6-8.

8 Prosecutor v Katanga, Judgment on the appeal of Mr Germain Katanga against the decision of Trial Chamber II of 21 November 2012 entitled "Decision on the implementation of regulation 55 of the Regulations of the Court and severing the charges against the accused persons", Dissenting Opinion of Judge Cuno Tarfusser, A. Ch., 27 March 2013, Case No. ICC-01/04-01/07-3363, paras. 15-16. 


\section{INTERPRETATIVE METHODOLOGY AND APPLICABLE LAW}

Before turning to the issue of modes of liability, it is necessary to first address the principles and sources that should guide the interpretation of the Statute in general and, more specifically, of different modes of liability. The question of interpretative principles should be distinguished from the question of applicable law, which is set out in Article 21 of the Statute, although the two often seem to be intertwined. ${ }^{9}$

\subsection{The Rome Statute and its interpretation}

Article 21(1) clearly establishes a hierarchy of sources. The Court should first apply its Statute, Elements of Crimes and Rules of Procedure and Evidence. Other sources of law specified in Article 2l(l) can only be applied if there is a lacuna which cannot be filled by interpreting the Statute and other primary sources (foremost by applying the criteria provided in Articles 31 and 32 of the Vienna Convention on the Law of Treaties and Article 21(3) of the Statute).$^{10}$ As noted by the Appeals Chamber, the Statute's provisions are to be interpreted in line with Article 31(1) of the Vienna Convention on the Law of Treaties. ${ }^{11}$ This means that provisions of the Statute, including that on modes of liability, must be interpreted in good faith in accordance with the ordinary meaning to be given to the language of the Statute, bearing in mind the relevant context and in light of its object and purpose. ${ }^{12}$

When interpreting the Statute, according to Article 31(3) of the Vienna Convention and considering the context, the Court should take into account "any relevant rules of international law applicable in the relations between

9 On that point, see L. Grover, 'A Call to Arms: Fundamental Dilemmas Confronting the Interpretation of Crimes in the Rome Statute of the International Criminal Court', 2010 European Journal of International Law, no. 21, pp. 549-550.

10 Prosecutor v Omar Hassan Ahmad Al Bashir, Decision on the Prosecutor's Application for a Warrant of Arrest against Omar Hassan Ahmad Al Bashir, Case No. ICC02/05-01/09-3, P-T. Ch. I, 4 March 2009 (hereinafter: First Al Bashir Arrest Warrant), para. 126.

11 Prosecutor v Thomas Lubanga Dyilo, Judgment pursuant to Art. 74 of the Statute, Case No. ICC-01/04-01/06-2842, T. Ch. I, 14 March 2012 (hereinafter: Lubanga Trial Judgment), with further references in footnote 2686. It is unclear why reference was made only to Article 31(1) and not to other paragraphs and Article 32.

121969 Vienna Convention on the Law of Treaties, 1155 United Nations Treaty Series (hereinafter: Vienna Convention), Article 31(1). 
the parties". It is argued that this provision enables reliance on international customary law not only as a subsidiary source of law, but as an interpretative tool..$^{13}$ It other words, whenever it is not clear that the drafters of the Statute purposely departed from it, the Statute should be interpreted in harmony with international customary law and other relevant rules of international law, i.e. general principles. Accordingly, ICTY/ICTR jurisprudence may be relevant for interpreting modes of liability pursuant to Article 25(3) inasmuch as it elucidates the existence of a rule of international law. ${ }^{14}$ Given the difference in approach, the ad hoc tribunals' case law cannot be 'transferred mechanically into the system of the Court' 15 and may only have a limited reach. Still, this provision may be seen as a powerful tool to avoid fragmentation and ensure coherence whenever possible. In fact, as noted by the European Court of Human Rights, the 'international law background to the legal question before it' must be taken into account even when considering the object and purpose of the treaty, as 'the common international or domestic law standards of ... States reflect a reality that the Court cannot disregard when it is called upon to clarify the scope of a Convention provision that more conventional means

13 See R. Bernhardt (ed.), Encyclopaedia of Public International Law, Vol. II, 1995, p. 1421; R. Wolfrum (ed.), The Max Planck Encyclopaedia of Public International Law, Vol. VI, 2012, p. 264; B. Goy, 'Individual Criminal Responsibility before the International Criminal Court, A Comparison with the Ad Hoc Tribunals', 2012 International Criminal Law Review, no. 12, p. 4. The so-called interpretation in conformity with customary law as a specific rule of interpretation in the field of international criminal law (whenever a treaty norm can be ascribed to a norm of customary law) is also highlighted by G. Werle, Principles of International Criminal Law 2009, p. 60 and V. Nerlich, 'The Status of the ICTY and ICTR Precedent in Proceedings before the ICC', in C. Stahn \& G. Sluiter (eds.), The Emerging Practice of the International Criminal Court, 2009, p. 319. Nerlich is, nevertheless, aware that this approach is open to criticism in the ICC context. First, it is questionable who the parties referred to in this provision are - State Parties or parties in a particular case. Moreover, it is unclear what is exactly meant by the notion of context and whether it refers to the law in force at the time of drafting of the Rome Statute or to the (customary international) law in force at the time of its interpretation (pp. 317-324).

14 But see Concurring opinion of Judge Van den Wyngaert, supra note 7, paras. 9-10. She is doubtful if customary international law may be drawn on by the ICC Chambers to interpret modes of liability and sees it only as a subsidiary source to be relied upon when there is a lacuna in the Statute.

15 This was pointed out by the Pre-Trial Chamber in Katanga. See Prosecutor v Katanga et al., Decision on confirmation of charges, Case No. ICC-01/04-01/07-717, P-T. Ch. I, 30 September 2008 (hereinafter: 'Katanga confirmation of charges'), para. 508. 
of interpretation have not enabled it to establish with a sufficient degree of certainty'. ${ }^{16}$

Finally, pursuant to Article 32 of the Vienna Convention, in cases of ambiguity or manifestly absurd or unreasonable results, recourse may be had to supplementary means of interpretation, including preparatory work.

Whereas the above described framework applies to Statute interpretation in general, when it comes to the specific issue of modes of liability one should also bear in mind Article 22 of the Rome Statute which lays down the principle of legality, the rule of strict construction and the principle of favor rei (interpretation in favour of the suspect or accused). The principle of legality undoubtedly applies equally to modes of liability as it does to definitions of crimes. ${ }^{17}$ Although Article 22(2) explicitly mandates strict construction only with respect to the definitions of crimes, this rule should apply equally to the interpretation of modes of liability ${ }^{18}$ since modes of liability form an integral unity with definitions of crimes and the mental element and are thus necessary to positively ground criminal responsibility from the perspective of substantive criminal law. Provisions on modes of liability link individual conduct to the crime and hence can be described as rules of imputation as opposed to grounds excluding responsibility. Only the latter may be extensively interpreted since such interpretation favours the accused. ${ }^{19}$

16 See Saadi v the United Kingdom, [2008] ECHR, GC, para. 63 and Demir and Baykara v Turkey, [2008] ECHR, GC, para. 76.

17 E.g., Prosecutor v Milutinovic and others, Decision on Dragoljub Ojdanic's Motion Challenging Jurisdiction - Joint Criminal Enterprise, Case No. IT-99-37-AR72, A. Ch., 21 May 2003, para. 21 (according to which the law providing for modes of liability must be sufficiently accessible at the relevant time so that the person who acts in that way must be able to foresee that he could be held criminally liable for his or her actions).

18 See Concurring opinion of Judge Van den Wyngaert, supra note 7, para. 18. The same view is shared by W. Schabas, supra note 1, p. 410. But see B. Broomhal, 'Article 22', in O. Triffterer (ed.), Commentary on the Rome Statute of the International Criminal Court: Observer's Notes, Article by Article, 2008, p. 724.

19 See K. Ambos, 'International Criminal Law at the Crossroads: From Ad Hoc Imposition to a Treaty-based Universal System’, in C. Stahn \& L. van den Herik (eds.), Future Perspectives on International Criminal Justice, 2010, p. 172. This view is supported by the text of the Statute itself since Article 31(3) gives the Court authority to consider other grounds of excluding criminal responsibility where such grounds can be derived from the applicable law as set out in Article 21. 


\subsection{Other sources of applicable law}

The secondary and tertiary sources of law described in Article 21(1)(b) and (c) can only be relied upon when interpretation of the Statute itself (and Elements of Crimes and Rules of Procedure and Evidence, where relevant) fails to provide a result. ${ }^{20}$ It is generally understood that the wording of Article 21(1) (b) includes rules of customary international law. Therefore, even if customary international law cannot be seen as an interpretative tool in light of Article 31(3) of the Vienna Convention, which is somewhat open to discussion ${ }^{21}$, it is germane as an autonomous, although subsidiary, source of law when the primary sources fail to prescribe a legal solution. The case law of the ICTY/ICTR hence may also be relevant here to the extent the Court finds it persuasive and reflective of the existence of a customary rule of international law (or even of a general principle).

As far as general principles of law are concerned, given the diversity of national legal systems in relation to defining modes of liability and punishing two or more persons who contribute to a crime in different ways, the role of general principles in interpreting modes of liability will likely be limited. ${ }^{22}$ Finally, even though the Court is not bound by its earlier decisions, it may apply principles and rules of law as interpreted in its previous decisions (Article $21(2)) .{ }^{23}$ In fact, the Court has already done so on a number of occasions. ${ }^{24}$ This pro-

20 Katanga Confirmation of Charges, supra note 15, para. 508.

21 See supra note 13.

22 There is a wealth of literature pointing to that conclusion. See, e.g., A. Cassese \& P. Gaeta, Cassese's International Criminal Law, 2013, p. 161; Judge Van den Wyngaert reaches the same conclusion in her Concurring opinion, supra note 7, para. 17 and so does G. Bitti, 'Article 21 of the Statute of the International Criminal Court and the Treatment of Sources of Law in the Jurisprudence of the ICC', in C. Stahn \& G. Sluiter (eds.), The Emerging Practice of the International Criminal Court, 2009, p. 300.

23 The provision does not make a difference between decisions of pre-trial, trial and appeals chambers.

24 See, e.g., Katanga Confirmation of Charges, supra note 15, para. 65 ('no compelling reason to depart') and The Prosecutor v Bemba, Decision pursuant to Article 61(7) (a) and (b) of the Rome Statute on the charges of the Prosecutor Against Jean Pierre Bemba Gombo, Case No. ICC-01/05-01/08-424, P-T. Ch. II, 15 June 2009 (hereinafter: 'Bemba Confirmation of Charges'), para 348 ('the Chamber finds no reason to deviate from the approach and line of reasoning embraced by Pre-Trial Chamber I, as it is consistent with the letter and spirit of Article 25(3)...'). 
vision contributes to the development of a consistent and predictable body of international criminal law and thus serves the principle of legality. ${ }^{25}$

\section{DISTINCTION BETWEEN PRINCIPAL AND ACCESSORIAL LIABI- LITY AND THE ISSUE OF A HIERARCHY OF BLAMEWORTHINESS}

The question of whether the Statute should be interpreted as providing for a differentiated and hierarchical system, which clearly distinguishes different forms of participation already at the level of imputation, has been seen as crucial for interpreting the modes of liability themselves. On the one hand, the Court has so far rather continuously relied on the distinction between principal liability (described in Article 25(3)(a)) and accessorial liability (described in 25(3)(b) to (d)) to draw conclusions about the content and scope of modes of liability. ${ }^{26}$ On the other, Judges Fulford and Van den Wyngaert strongly reject such a reading of Article 25(3) and, consequently, dismiss the Court's efforts to develop theoretical guidelines that would enable the delimitation of different modes of liability to avoid an overlap. According to Judge Fulford, 'the plain language of Article 25(3) demonstrates that the possible modes of commission under Article 25(3)(a)-(d) of the Statute were not designed to be mutually exclusive'. ${ }^{27}$

The plain text of Article 25(3) does not provide an unambiguous answer as to whether there is a hierarchy of seriousness ${ }^{28}$, and makes it plausible to embrace the unitary reading and regard Article 25(3) as containing overlap-

25 M. de Guzman, 'Article 21', in O. Triffterer (ed.), Commentary on the Rome Statute of the International Criminal Court: Observer's Notes, Article by Article, 2008, p. 711.

26 See, e.g., Prosecutor v Thomas Lubanga Dyilo, Decision on Confirmation of Charges, Case No. ICC-0 1/04-0 1/06-803-tEN, P-T. Chamber I, 29 January 2007 (hereinafter: Lubanga Confirmation of Charges), para. 320. Katanga Confirmation of Charges, supra note 15, para. 518 implicitly endorses not just the lesser blameworthiness of accessories, but also the lesser degree of blameworthiness of "merely order[ing]" in comparison to committing (through an organization). See also Lubanga Trial Judgment, supra note 5, para. 999 in which the Court said that 'lowering the threshold [of the accused's contribution] would deprive the notion of principal liability of its capacity to express the blameworthiness of those persons who are the most responsible for the most serious crimes of international concern'.

27 Separate opinion of Judge Fulford, supra note 5, para. 8.

28 For arguments in favour of both readings, see A. Eser, 'Individual Criminal Responsibility', in A. Cassese et al. (eds.), The Rome Statute of the International Criminal Court: A Commentary, 2002, pp. 787-788. 
ping modalities of participation. ${ }^{29}$ Yet, most scholars read the dualist model into this provision. ${ }^{30}$ Indeed, the wording and separation of different modes of liability into distinct categories seem to demonstrate the preference for the differentiated model, especially when compared to truly 'monist' wording. ${ }^{31}$ The mere fact that there may be some overlapping of some subsections of Article 25(3), foremost between ordering and committing through another person, does not militate against the distinction but, on the contrary, calls for an interpretation which helps to avoid such an overlap and the resulting redundancy. ${ }^{32}$ Along the same lines, the ECHR has emphasized that a provision must be interpreted and applied 'in a manner which renders its rights practical and effective, not theoretical and illusory'. It further endorsed systematic interpretation when it stressed that the Convention must be read 'as a whole, and interpreted in such a way as to promote internal consistency and harmony between its various provisions'. ${ }^{33}$

Another argument in favour of the principal-accessory dichotomy, as pointed out by the Trial Chamber in the Lubanga judgment, can be found in the derivative nature of modes of liability described in Article 25(3)(b) to (d). The provision's wording clearly reflects the difference between liability for

29 See, e.g., M. Dubber, 'Criminalizing Complicity. A Comparative Analysis', 2007 Journal of International Criminal Justice, no. 5, p. 1000, who believes that the Rome Statute does not differentiate categorically between principals and accomplices. According to E. van Sliedregt, Individual Criminal Responsibility in International Law, 2012, p. 86, '[t] he better view is to regard Article 25(3)(a) as containing overlapping modalities of perpetration and participation'. Yet, she seems to endorse the principal-accessory classification, mostly for fair labelling reasons (see p. 80).

30 See, e.g., K. Ambos, 'Article 25', in O. Triffterer (ed.), Commentary on the Rome Statute of the International Criminal Court: Observer's Notes, Article by Article, 2008, p. 746; Werle, supra note 13, p. 169; Schabas, supra note 18, pp. 424, 430431 ; S. Wirth, 'Co-perpetration in the Lubanga Trial Judgment', 2012 Journal of International Criminal Justice, no. 10, p. 978; Yanev \& Kooijmans, supra note 2, p. 804; S. Manacorda \& C. Meloni, 'Indirect Perpetration versus Joint Criminal Enterprise. Concurring Approaches in the Practice of International Criminal Law?', 2011 Journal of International Criminal Justice, no. 9, p. 167.

31 Wirth, ibid., p. 979, who quotes an Austrian provision as an example of a monist approach.

32 Such an interpretation may be seen as consistent with the doctrine 'ut res magis valeat quam pereat'. For a plausible delimitation between ordering and indirect perpetration, see Goy, supra note 13, p. 55.

33 See, e.g., Stec and Others v. the United Kingdom, [2005] ECHR, GC, Decision as to the admissibility of the Applications nos. 65731/01 and 65900/01 by Stec and others against the United Kingdom 6 July 2005, paras. 47-48. 
one's own conduct and for a crime committed by another. Secondary liability depends on whether the perpetrator at least attempted to commit the crime. ${ }^{34}$ Along the same lines, only those individuals who attempted to commit the crime are criminalized and not those who attempted to participate in a crime as accessories.

Distinguishing between principals and accessories and between degrees of responsibility can be seen as an expression of the 'normative' or 'top-down' approach, which focuses on the notion of responsibility to pinpoint those who had a decisive influence on the commission of the crime and should therefore be considered principals. ${ }^{35}$ Not labelling as principal the liability of those at the top of the chain, even when they do not physically carry out the elements of an offence, would seem to reject the didactic purposes of the system of international criminal justice and the often perceived need to establish a historical record. ${ }^{36}$ This value-based approach to criminal participation goes hand in hand with the purpose of the provision in light of the overarching goals of the Rome Statute and its unavoidable focus on the senior, most responsible perpetrators. ${ }^{37}$ One could argue, in contrast, that the purpose of the Statute could only be referred to when deciding whom to charge and not how to charge. Yet, military and political leaders may assume different roles and not distinguishing between them depending on their actual impact on the commission of crimes would, arguably, defeat the expressive functions of international criminal justice described above. Moreover, in light of experienced evidentiary pitfalls the Office of the Prosecutor (OTP) has recently been re-evaluating its original strategy that emphasizes the criminal responsibility of the most responsible senior leaders. Proving their criminal responsibility and gradually building upwards may require the prosecution to investigate and prosecute a limited number of mid- and high-level perpetrators in order to ultimately have

34 Lubanga Trial Judgment, supra note 11, para. 998.

35 For more about this approach and its opposite, naturalistic or empirical approach, see J. D. Ohlin et al., 'Assessing the Control-Theory', 2013 Leiden Journal of International Law, no. 26, pp. 740-743.

36 M. Damaska, 'What is the Point of International Criminal Justice?', 2008 ChicagoKent Law Review, no. 83, p. 343 et seq.; War Crimes Research Office, Modes of Liability and the Mental Element, Analysing Early Jurisprudence of the International Criminal Court, 2010, p. 57, <http://www.wcl.american.edu/warcrimes/icc/documents/report13. pdf $>$, (last visited 4 May 2014).

37 H. Friman et al., 'Charges', in G, Sluiter et al. (eds.), International Criminal Procedure. Principles and Rules, 2013, p. 391. 
a reasonable chance to convict the most responsible'. ${ }^{38}$ The OTP has also made public its internal policy decision to prosecute even lower level perpetrators where their conduct has been particularly grave and has acquired extensive notoriety. That approach will, it is hoped, be more cost-effective than having unsuccessful or no prosecutions against the highest placed perpetrators. ${ }^{39}$ In light of this strategy, distinguishing between different categories of principals and between principals and accessories seems even more important.

However, some scholars claim that adherence to differentiated modes of liability reduces the expressive value of international trials since different modes of liability are unlikely to be fully comprehended within the national jurisdictions in which the crimes took place. ${ }^{40}$ Indeed, some domestic criminal law systems do not place an emphasis on the distinction between principles and accessories, at least not before the sentencing stage. Still, the distinction between perpetrators or principals on the one side and accessories or secondary parties, on the other, has been embraced by most national criminal justice systems. ${ }^{41}$ It is therefore legitimate to maintain that a sophisticated understanding of the defendant's relation to the offence is necessary to fulfil the expressive function of international criminal law. Making clear who the 'real' culprit is, i.e. referring to those who masterminded the crimes as principals, is important in communication with victims and carries the denunciatory and educational function. ${ }^{42}$ This is also in line with the so-called principle of fair labelling. ${ }^{43}$ In the context of the inherently collective nature of international crimes it may be seen as particularly important to ascertain the specific role of each participant. ${ }^{44}$

38 Office of the Prosecutor, Strategic Plan, June 2012-2015, 11 October 2013, para. 22, <http://www.icc-cpi.int/en_menus/icc/structure $\% 20$ of $\% 20$ the $\% 20$ court/office $\% 20$ of $\% 20$ the $\% 20$ prosecutor/policies $\% 20$ and $\% 20$ strategies/Documents/OTPStrategic-Plan-2012-2015.pdf> (last visited 4 May 2014).

39 Ibid.

$40 \quad$ See Stewart, supra note 3, p. 215. But see Damaska, supra note 36, p. 353.

41 H. Olasolo, The Criminal Responsibility of Senior Political and Military Leaders as Principals to International Crimes, 2010, p. 15.

42 This was even recognized by van Sliedregt who in principle argues against hierarchical ranking and a strict distinction. See van Sliedregt, supra note 2, p. 1185 , with further references.

43 For more on the origins of the principle and its meaning, see Stewart, supra note 3, p. 176.

44 Comp. T. Weigend, 'Perpetration through an Organization. The Unexpected Career of a German Legal Concept', 2011 Journal of International Criminal Justice, no. 9 , p. 102. See further references in footnote 48. 
Another argument in favour of the differential reading of this provision may be found in the preparatory works on Article $25^{45}$, as well as in the ICTY case law as reflective of the fact that the dualist approach has most likely evolved into a customary rule of international law. Although, on the face of it, Article 7(1) of the ICTY Statute could be seen as establishing a unitary system, the ICTY Appeals Chamber has quite consistently embraced the distinction between perpetration giving rise to principal liability and participation in a crime committed by a third person giving rise to accessorial liability (and has thus distanced itself from the IMT and IMTFE, which adopted the unitary model) ${ }^{46}$

Accessorial liability, at least in the normative model, connotes lesser liability ${ }^{47}$, and this is precisely what Judge Van den Wyngaert rejects. On the other hand, Judge Fulford seems to be proposing that if any differentiation in the degree of responsibility is to be made, it is to be left for judicial determination of the punishment and not the imputation of guilt. Yet, while it is argued that differentiation in terminology and placement in separate categories would be superfluous if it did not imply different degrees of individual guilt to be taken into account when meting out the punishment ${ }^{48}$, admittedly neither the Statute nor the RPE attach strict legal consequences to such a determination, and accessorial modes of liability do not result in any automatic reduction of punishment for accessories. ${ }^{49}$

45 Yanev \& Kooijmans, supra note 2, p. 804.

46 Comp. Prosecutor v Krnojelac, Judgment, Case No. IT-97-25-A, A. Ch., 17 September 2003, paras. 30, 73; Prosecutor v Krstic, Judgment, Case No. IT-98-33-A, A. Ch., 19 April 2004 (hereinafter: 'Krstic Appeals Judgment'), paras. 266-269; Prosecutor v Kvocka et al., Judgment, Case No. IT-98-30/1-A, A. Ch., 28 February 2005, paras. 79-91. H. Alonso, 'Current Trends on Modes of Liability for Genocide, Crimes Against Humanity and War Crimes', in C. Stahn \& L. van den Herik (eds.), Future Perspectives on International Criminal Justice, 2010, pp. 522-524.

47 Schabas, supra note 1, p. 431. The same point is made by Manacorda \& Meloni, supra note 30, p. 161.

48 Comp. Werle, supra note 13, p. 169; Manacorda \& Meloni, supra note 30, p. 167.

49 The Statute itself does not explicitly provide that the mode of responsibility should influence the determination of a sentence, whereas under Rule of Procedure and Evidence 145(1)(c) the degree of participation of the convicted person is specified as only one of the relevant factors that should be taken into account. This seems to be the main argument of the majority in Katanga case for rejecting the hierarchical relationship between different forms of participation described in Art. 25(3). See Prosecutor v Katanga, Jugement rendu en application de l'article 74 du Statut, Case No. ICC-01/04-01/07-3436, T.Ch. II, 7 March 2014 (hereinforth: Katanga Trial Judgment), paras. 1386-1387. 
The ICTY has explicitly considered only aiding and abetting as a lesser form of liability, which as a matter of principle attracts reduced sentences. ${ }^{50}$ This has led some scholars to accept the hierarchical relation, i.e. lesser blameworthiness in the ICC framework only with regard to Article 25(3)(c). ${ }^{51}$ Still, while different interpretations remain possible, already at first glance Article 25(3)(d) seems to set a lower threshold than Article 25(3)(c), both with regard to the objective ('in any other way contributes' arguably requires a smaller form of contribution than Article 25(3)(c)) and the subjective element (Article 25(3)(d) does not require a purpose of facilitating), which would speak in favour of a further gradation in blameworthiness. ${ }^{52}$ The Court has explicitly, on several occasions, understood this provision as serving as a residual mode of accessorial liability that is only triggered when the requirements of subparagraphs (a)-(c) are not met..$^{53}$

With regard to Article 25(3)(b), in the Katanga Confirmation of Charges decision, the Pre-Trial Chamber implicitly held that ordering was a less serious mode of liability than indirect perpetration and the same conclusion could be made, a fortiori, with respect to the other modes of liability specified in Article 25(3)(b). ${ }^{54}$ But even if ordering cannot be deciphered as less blameworthy

50 Comp. Prosecutor v Vasiljevic, Judgment, Case No. IT-98-32-A, A. Ch., 25 February 2004, paras. 181-182, Krstic Appeals Judgment, supra note 46, paras. 266-275, Prosecutor v Mrksic and Sljivancanin, Judgment, Case No. IT-95-13/1-A, A. Ch., 5 May 2009, para. 407.

51 This view is expounded by Ohlin et al., supra note 35, p. 744.

52 Kai Ambos recently departed from his own, similar view that the wording "in any other way" implies a lower threshold of objective contribution in comparison to Art. 25(3)(c). He now argues that, in substance, both subparagraphs (c) and (d) provide for assistance liability and while both modes of liability may be seen as less blameworthy than liability of (co)perpetrators described in subparagraph (a), further distinction between (c) and (d) cannot be made. See K. Ambos, 'The ICC and Common Purpose: What Contribution is Required Under Article 25(3)(d)?' in C. Stahn (ed.), The Law and Practice of the ICC: A Critical Account of Challenges and Achievements, 2014, Forthcoming. Available at SSRN: <http://ssrn.com/ abstract $=2411981>($ last visited 6 May 2014).

53 Prosecutor $v$ William Samoei Ruto and Joshua Arap Sang, Decision on the Confirmation of Charges Pursuant to Article 61(7)(a) and (b) of the Rome Statute, Case No. ICC-01/09-01/11-373, 23 January 2012, P-T. Ch. II, (hereinafter: Ruto et al. Confirmation of Charges), para. 354: Prosecutor v Mbarushimana, Decision on the Confirmation of Charges, Case No. ICC-01/04-01/10-465-Red 16, P-T. Ch. I, December 2011 (hereinafter: Mbarushimana Confirmation of Charges), paras. 278-279.

54 Katanga Confirmation of Charges, supra note 15, para. 518. 
than the modes of liability described in Article 25(3)(a), this is not a valid argument to reject the dualist reading and the dogmatic distinction between different modes of liability altogether. A distinction between perpetration (principal liability) and participation (accessorial liability) is not necessarily followed by the mitigation or aggravation of punishment, and this is also not the case in all national jurisdictions that follow a dualist approach. ${ }^{55}$ The degree of participation is just one of the relevant factors when determining the sentence. Nevertheless, even if different modes of liability do not categorically bear upon the level of punishment, as long as the law provides for different modes of liability these labels should be used consistently and Article 25(3) should be interpreted as containing four distinct and mutually exclusive modes of liability to be determined at the level of attribution. ${ }^{56}$ As far as the controversial issue of hierarchical relationship between different modes of liability is concerned, it could be convincingly argued that Article 25(3)(a)-(d) is best construed as establishing four hierarchical levels of criminal responsibility with commission at the top, but currently there is an apparent divide within the Court. $^{57}$

In conclusion, a dualist reading of the provision, as setting clearly defined and distinguishable modes of liability, seems to be in harmony with the principle of legality as expressed in Article 22 of the Statute. ${ }^{58}$ Such a reading appears to be supported by the requirement of specificity (lex certa) which does not give the impression of being guarded by Judge Fulford's loose approach enabling 'a clear degree of crossover between the various modes of liability'. From the perspective of accomplices at least, attributing smaller degrees of blameworthiness to Article 25(3)(b) to (d) is also supported by the principle of favor rei.

55 Van Sliedregt, supra note 29, pp. 70-71.

56 Comp. Ohlin et al., supra note 35, p. 729 and Werle, supra note 13, p. 169.

57 Werle argues that the value-oriented hierarchy of participation in a crime under international law stems from both the linguistic differentiation and the conceptual systematization of the norm. See G. Werle, 'Individual Criminal Responsibility', 2007 Journal of International Criminal Justice, no. 5, p. 957. On the other hand, whereas the Lubanga Trial Chamber (I) expressed itself in favour of the hierarchy, Trial Chamber II in Katanga rejected such reading of Art. 25(3). Comp. Lubanga Trial Judgment, supra note 11, para. 996 and Katanga Trial Judgment, supra note 49, para. 1386.

58 Wirth, supra note 30, p. 979. See also V. Militello, 'The Personal Nature of Individual Criminal Responsibility and the ICC Statute', 2007 Journal of International Criminal Justice, no. 5, p. 949. 


\section{THE PROPOSED CONCEPTUAL FRAMEWORK FOR INTERPRE- TING MODES OF LIABILITY}

\subsection{Rejecting objective and subjective theories of perpetration}

The ICC has so far consistently relied on the 'control of the crime' concept as a decisive factor for distinguishing between perpetrators and accessories. ${ }^{59}$ Therefore, the control over the crime approach, at least to some extent, emerges from the endorsement of the dualist approach. That is to say, according to the Court neither subjective nor objective theories can offer a reasonable explanation and coherent framework for differentiating between different modes of liability. ${ }^{60}$

The Court has rejected objective theories, which generally restrict the category of principals to those who physically carry out the actus reus of an offence, based on the fact that the Statute clearly classifies as perpetrators those who commit a crime through another person (Article 25(3)(a)). ${ }^{61}$ At the same time, the Court has declined to follow the subjective approach and its manifestation in the ICTY case law, the concept of joint criminal enterprise - reasoning that the degree of contribution to a crime, and not the state of mind, should be a central element in determining the liability of principals. It has further relied on the distinction between Article 25(3)(a) and (d), arguing that had the drafters of the Statute opted for a subjective approach to distinguish between principals and accessories, those described in Article 25(3)(d) would be considered principals and not accessories to a crime, which was clearly not the case due to the explicit residual nature of that mode of liability ${ }^{62}$ In addition, as the Court reiterated, the 'control of the crime' paradigm represents a plausible

59 See Lubanga Confirmation of Charges, supra note 26, paras. 327, 332-341, reiterated in the Lubanga Trial Judgment, supra note 11, paras. 918-923. See also First Al Bashir Arrest Warrant, supra note 10, para. 210; Katanga Confirmation of Charges, supra note 15, paras. 480-486; Ruto et al. Confirmation of Charges, supra note 53, para. 291, Prosecutor v Francis Kirimi Muthaura, Uhuru Muigai Kenyatta and Mohammed Hussein Ali, Decision on the Confirmation of Charges Pursuant to Article 61(7)(a) and (b) of the Rome Statute, Case No. ICC-01/09-02/11-382Red P-T. Chamber II, 23 January 2012 (hereinafter: Kenyatta Confirmation of Charges), para. 296. For the most recent endorsement of the theory, see Katanga Trial Judgment, supra note 49, paras. 1382, 1394-1396.

60 Obviously, this is not a valid argument for Judge Fulford, who rejects the dualist reading from the outset.

${ }_{61}$ The term 'commission' is generally considered as synonymous with 'perpetration'. On that point see Schabas, supra note 18, p. 427.

62 The Court also compared Article 25(3)(d) with the concept of joint criminal enterprise. 
normative theory to hold responsible as perpetrators those participants who may have been remote from the scene of the crime, but still masterminded its commission, i.e. decided whether and how the offence would be committed. ${ }^{63}$ Finally, the Court seems to have relied on subsidiary sources of law when it found the control theory to be widely recognized and applied in a number of legal systems and supported in the modern legal doctrine. ${ }^{64}$ Yet it remains unclear if the Court was implying that the theory formed part of international customary law or the general principles of law, as well as whether it referred to the doctrine in an attempt to establish the existence of 'teachings of the most highly qualified publicists of the various nations, as subsidiary means for the determination of rules of law' in the sense of Article 38 of the ICJ Statute. Perhaps it could be argued that the Court implicitly found the 'control of the crime' concept to be rooted in a literal, systematic and contextual interpretation of the Statute in light of its object and purpose. ${ }^{65}$ Yet, others disagree, claiming that nothing in the text of the Statute or in its drafting history suggests that the Statute codified this theory. ${ }^{66}$ In addition, it is contended that if subsidiary sources are to be relied upon at all $^{67}$, they should be interpreted as an argument in favour of subjective theories, as will be explained below.

Whereas the dismissal of purely objective theories can find quite strong support on the basis of a textual and structural interpretation of the Statute, foremost due to the fact that a crime can be committed through another blameworthy person (Article 25(3)(a)), the rejection of subjective theories needs to be further scrutinized because it largely depends on the interpretation of

63 Lubanga Trial Judgment, supra note 11, para. 920; Katanga Confirmation of Charges, supra note 15, para. 485; Lubanga Confirmation of Charges, supra note 26, para. 330 .

64 Katanga Confirmation of Charges, supra note 15, para. 485 with further references in footnote 647. On the other hand, Trial Chamber II in the same case later emphasized that whether the theory is recognized in various national laws is not decisive as the Court must foremost apply its own statute. See Katanga Trial Judgment, supra note 49, para. 1395.

65 This would seem to be the position of the Trial Chamber II in Katanga case, when it found control over the crime theory to represent the guiding principle inherent in Art. 25(3), which makes the distinction between perpetrators of a crime and their accomplices effective and allows all the relevant provisions of this Article relating to individual criminal responsibility to produce their full effect. Ibid.

66 Comp. van Sliedregt, supra note 29, page 86. Separate opinion of Judge Fulford, supra note 5, para. 6 et seq.; Concurrent Opinion of Judge Van den Wyngaert, supra note 7 , para. 30 .

67 Advocating a cautious approach in this regard, Concurrent Opinion of Judge Van den Wyngaert, ibid., para 17. 
Article 25(3)(d). Some scholars argue that Article 25(3)(d) is not a manifestation of or a similar form to JCE, but a variation of aiding and abetting, namely, aiding and abetting group criminality and not individual criminality ${ }^{68}$ The motivation behind this assertion lies in the proposition that if Article 25(3) (d) does not codify JCE, the ICC would be free to import it into Article 25(3) (a) ${ }^{69}$ Indeed, the two concepts cannot be completely equated. To start with, Article 25(3)(d) surely does not incorporate JCE III because it does not provide for dolus eventualis. ${ }^{70}$ In addition, if the dualist interpretation of Article 25(3) is accepted, as proposed in the previous section, Article 25(3)(d), unlike JCE, cannot be seen as a form of perpetration, but participation, i.e. accessorial liability. ${ }^{71}$ Another major difference between the JCE and Article 25(3)(d) responsibility, it has been advanced, is that a defendant under Article 25(3)(d) does not have to be a member of a group sharing a criminal purpose, but may be an outsider who assists others who are acting with a common purpose. ${ }^{72}$ This allows the conclusion that the mode of liability described in Article 25(3) (d) is simply another form of aiding and abetting - aiding and abetting group criminality, instead of that of an individual. ${ }^{73}$ The last argument, however, is not convincing. Reducing Article 25(3)(d) to a simple variant of aiding and abetting would render it redundant because the objective threshold prescribed in Article 25(3)(c) is already very low. ${ }^{74}$ Moreover, Article 25(3)(d) makes no reference to an inside or outside status at all and, in any case, accomplice liability is not predicated on a determination that the defendant is not a member of a criminal group. ${ }^{75}$ Finally, nothing in the wording of Article 25(3)(c) suggests that it only incriminates aiding and abetting an individual. Therefore, for the purposes of this analysis it may be concluded that Article 25(3)(d) closely resembles JCE inasmuch as it reflects the idea of furthering common purpose

68 Yanev \& Kooijmans, supra note 2, p. 802. Similar views have been expounded by Ambos, who distinguishes between Article 25(3)(c) and (d) on a subjective level, see Ambos, supra note 30, p. 769.

69 As observed by J. Ohlin, 'Joint Criminal Confusion', 2009 New Criminal Law Review, no. 12, p. 412. This would seem to be the line of argument in Cassese's International Criminal Law, supra note 22, p. 175.

70 Van Sliedregt, supra note 29, p. 146.

71 Schabas, supra note 18, p. 436. For an articulate list of other differences, see Mbarushimana Confirmation of Charges, supra note 53, para. 282.

72 Yanev \& Kooijmans, supra note 2, pp. 801-803.

73 Ohlin, supra note 69, pp. 411-412.

74 Eser, supra note 28, p. 803.

75 Ohlin, supra note 69, pp. 411-412. This proposition was also rejected by the Court, see Mbarushimana Confirmation of Charges, supra note 53, paras. 272-273. 
liability, which has been at the core of JCE liability at the ICTY. ${ }^{76}$ Both concepts emphasize subjective elements and not an objective contribution.

Yet, the subjective approach is also favoured based on the perceived need to avoid further fragmentation of international criminal law and any departure from the jurisprudence of the ad hoc tribunals. When interpreting the concept of commission introduced in Article 25(3)(a), the Court should, it is contended, draw upon customary international law which clearly endorses the subjective approach based on the JCE. ${ }^{77}$ Notwithstanding the appeal of this assertion, customary international law is a subsidiary source of law that can only be taken into account if: a) there is a lacuna; and b) it is not clear that the drafters of the Rome Statute created an independent body of law that must be interpreted independently. ${ }^{78}$ The wording of Article 25(3)(a) manifestly rejects ICTY/R jurisprudence as a basis for interpreting the concept of commission, which is evident in the fact that it explicitly endorses the concept of indirect perpetration - a mode of liability not recognized as such by the ICTY and not applied by international criminal judiciary before the Rome Statute entered into force. ${ }^{79}$ In addition, if the words 'jointly with another' were to

76 E.g., Ohlin argues that Article 25(3)(d) represents a statutory surrogate for JCE, ibid., p. 409. Similarly, T. Weigend, 'Intent, Mistake of Law, and Co-perpetration in the Lubanga Decision on Confirmation of Charges', 2008 Journal of International Criminal Justice, no. 6, p. 478, who believes that Article 25(3)(d) certainly opens the door for the JCE doctrine. Van Sliedregt, supra note 29, p. 146 points out that JCE could come under 25(3)(d) under alternative (i) where proof of shared intent is needed; Boas claims that 25(3)(d) clearly refers to a theory of common purpose liability which is consistent with the JCE as developed by the ICTY. See G. Boas, 'The Difficulty with Individual Criminal Responsibility in International Criminal Law', in C. Stahn \& L. van den Herik (eds.), Future Perspectives on International Criminal Justice, 2010 , p. 516.

77 This seems to be a general plea of van Sliedregt, ibid., p. 16, in order to develop an integrated and consistent system of international criminal justice. See also Yanev \& Kooijmans, supra note 2, p. 827. The Court has recently, however, emphasised that unlike international ad hoc tribunals, the ICC is not under an obligation to research if a certain rule or interpretation comports to international customary law. See Katanga Trial Judgment, supra note 49, para. 1395.

78 The latter equally applies to reliance on customary international law as an interpretative tool. Werle, supra note 13, p. 176.

79 For an overview of cases before the ICTY/R that demonstrate certain elements of indirect co-perpetration theory, see Cassese's International Criminal Law, supra note 22, p. 179. Apart from the Stakic Trial Judgment, which was overturned on appeal, the jurisprudence of the ICTY/ICTR has not used the term indirect perpetration when assessing situations such as that found in the Seromba case, nor when convicting under JCE for crimes physically carried out by non-JCE members. See Goy, supra note 13, p. 40. 
be interpreted to include common purpose liability akin to JCE (I or II), the drafters would have used the same terminology as in Article 25(3)(d) - and incriminated the commission of 'a crime by a group of persons acting with a common purpose'. Any interpretation reading common purpose liability into Article 25(3)(a) would violate the basic rule of interpretation - that differences in wording exist for a reason, i.e. that they reflect differences in content. ${ }^{80}$

\subsection{The 'control of the crime' paradigm}

However, it must be admitted that setting aside subjective theories and the JCE concept cannot automatically be interpreted as the legal basis for adopting the control over the crime theory. ${ }^{81}$ Nevertheless, the dismissal of subjective theories coupled with the rejection of purely objective theories strongly speaks in favour of adopting a mixed, objective-subjective model of perpetration such as that expressed by control theory. Control of the crime theory, furthermore, provides for probably the most reasonable common denominator for different modes of principal liability specified in Article 25(3)(a), at least if subjective interpretation is rejected - it brings together, under the umbrella terms of 'control' and 'commission', several modes of conduct (act-domination in the case of individual commission, functional domination in the case of co-perpetration and will domination when it comes to indirect co-perpetration) ${ }^{82}$ Evidently, control theory is based on the writings of the German scholar Roxin, i.e. on modern German theory and on just a handful of systems that follow it. Not only does this theory not form part of international customary law or general principles of law, but it is even questioned in the country of its origin. ${ }^{83}$ Yet, contrary to Judge Van den Wyngaert's view that reliance on 'control of the crime' theory would be permissible only inasmuch as it qualified as a general principle of law in the sense of Article $21(1)(c)^{84}$, a theoretical approach may provide a coherent framework for interpreting the Statute. ${ }^{85}$ Along these

80 Ohlin, supra note 69, p. 416.

81 Yanev \& Kooijmans, supra note 2, p. 798.

82 N. Jain, 'The Control Theory of Perpetration in International Criminal Law', 2011 Chicago Journal of International Law, no. 12, p. 165. See also Lubanga Confirmation of Charges, supra note 26, para. 332.

83 Weigend, supra note 44, p. 99 and van Sliedregt, supra note 29, p. 87.

84 Concurring opinion of Judge Van den Wyngaert, supra note 7, para. 17. This also seems to be the conclusion of Judge Fulford, Separate opinion of Judge Fulford, supra note 5, para. 10 .

85 In continental legal systems, this is sometimes expressed by an old Latin tag praxis sine theoria caecus in via. See M. R. Damaska, 'A Continental Lawyer in an American 
lines, Ambos argues that the validity of a theory is not geographically or culturally limited. Instead, its reach depends on its persuasiveness. ${ }^{86}$ Subsidiary and tertiary sources of law would, hence, only become relevant if the Statute could not be interpreted in a reasonable manner. It is to be emphasized that, while the Court strongly adheres to the principle of legality, thus rejecting the judicial creation of law, judicial interpretation remains necessary to interpret dogmatic concepts such as commission and this is where doctrine is indispensable. As noted by the European Court of Human Rights, '[i]n any system of law, including criminal law, however clearly drafted a legal provision may be, there is an inevitable element of judicial interpretation. There will always be a need for elucidation of doubtful points and for adaptation to changing circumstances' ${ }^{87}$ As long as the interpretation is foreseeable and accessible, it does not violate the principle of legality. ${ }^{88}$ In fact, the ECHR has found that one of the circumstances making judicial interpretation reasonably foreseeable is the fact that such an interpretation was supported by a number of scholars at the relevant time of the commission of the crime..$^{89}$ Obviously, the ICC's interpretation of modes of liability, unlike interpretation according to the principles propounded by the ECHR, should be guided by the rule of strict construction and the favor rei principle..$^{90}$ Although this may not appear at first glance, the result of 'control of the crime' theory application seems to be in line with the rule of strict construction and the favor rei principle much more than the application of any subjective test. Grounding commission on the subjective state of mind potentially broadens the class of perpetrators and leaves

Law School: Trials and Tribunals of Adjustment', (1968). Faculty Scholarship Series. Paper 1592. <http://digitalcommons.law.yale.edu/fss_papers/1592/>, (last visited 4 May 2014). A similar view seems to have been taken by the Trial Chamber II in Katanga when it referred to the 'guiding principle' (le principe directeur). See Katanga Trial Judgment, supra note 49, para. 1395.

Ambos, supra note 4, p. 143

Jorgic v Germany, [2007] ECHR, para. 101.

In the context of the European Convention, an interpretation may even be progressive. The ECHR emphasized that Article 7 of the Convention cannot be read as outlawing the gradual clarification of the rules of criminal liability through judicial interpretation, provided that the resultant development is consistent with the essence of the offence and could reasonably be foreseen (see, inter alia, S.W. $v$ the United Kingdom, [1995] ECHR, para. 36; C.R. v the United Kingdom, [1995] ECHR, para. 34; Streletz, Kessler and Krenz v. Germany, [2001] ECHR, para. 50; and K.-H.W. v. Germany, [2001], ECHR, GC, para. 45.

89 Jorgic v Germany, supra note 87, para. 107. This could well be the case here given the number of scholarly writings making 'control of the crime' theory reasonably foreseeable. See, e.g., Werle, supra note 57.

90 Which is not the case before many national jurisdictions and the ECHR. 
room for manipulation ${ }^{91}$, whereas requiring control as an objective requirement in abstracto serves to restrict the reach of this, highest degree of individual criminal responsibility.

\section{CONCLUSION}

Several issues regarding modes of liability are still open for discussion and the debate is ongoing. This paper deals with only a fragment of this subject matter (that of the overarching theory), leaving the discussion of particularities of each mode of liability aside. In contrast to what some scholars and practitioners advance, objective and subjective elements of different modes of liability can only be ascertained following the determination of the guiding principles. In other words, one should first seek to answer whether Article 25(3) provides for a unitary or dualist approach and, if the dualist approach is accepted, where the line should be drawn between commission and accomplice liability. Certainly, there is merit to the argument that the Court should strive to achieve greater harmonization with the jurisprudence of the ad hoc tribunals in order to avoid unnecessary fragmentation of international criminal law. Yet, this should not be done at the expense of the Court's internal consistency and coherence. Although the Court is not bound by its previous decisions, it may apply principles and rules of law as interpreted in its previous decisions (Article 21(2)). As stated above, such a practice contributes to the development of a consistent and predictable body of international criminal law and consequently serves the principle of legality. ${ }^{92}$ The Court has so far persistently followed the path of control theory which, as explained above, can be viewed as coherent and grounded in the Statute. While minor aberrations from the main route can be seen as fine-tuning ${ }^{93}$, making what may be seen as a U-turn in this field could undermine the Court's legitimacy and its adherence to important general principles of international criminal law. The (appellate) judges of the ICC should keep this in mind when rethinking the content and scope of different modes of liability.

$91 \quad$ Weigend, supra note 76, p. 480.

92 DeGuzman, supra note 25, p. 711.

93 Upholding the control theory does not necessarily imply endorsing the current interpretation of all the elements of different modes of liability. For example, questions such as what is meant by 'essential contribution' in the context of coperpetration, whether the concept of indirect (co-)perpetration is inextricable from control over an organization, and so on, should be a matter of further discussion and analysis. Similar point has recently been made by K. Ambos, 'A Workshop, a Symposium and the Katanga Trial Judgment of 7 March 2014', 2014 Journal of International Criminal Justice, no. 12, p. 229. 
Summary

Maja Munivrana Vajda*

\section{RAZLIKOVANJE POČINITELJA I SUDIONIKA PRED MKS-Om - DRUGI POGLED NA TEORIJU VLASTI NAD DJELOM}

Umjesto da dokine rasprave o tom pitanju, prva presuda Međunarodnog kaznenog suda (MKS) u predmetu Lubanga, kojom je podržana teorija o vlasti nad djelom, kao da je otvorila Pandorinu kutiju različitih pristupa oblicima individualne kaznene odgovornosti pred MKS-om. I praktičari i pravni teoretičari uključili su se u uzavrele pravne debate o pravilnom tumačenju članka 25. stavka 3. Rimskog statuta. Kritičari teorije o vlasti nad djelom ispravno ističu kako se ta teorija ne može jednostavno izvesti iz izričaja relevantne odredbe samog Statuta i stoga ne predstavlja jedinu prihvatljivu teoriju. No, s druge strane, zastupanje stava kako sam tekst članka 25. stavka 3. nudi jednostavan $i$ jasan uvid u sadržaj i doseg svakog pojedinog oblika kaznene odgovornosti čini se pomalo naivnim. Izričaj članka 25. neodređen je i ostavlja prostor za različita gledišta, kao što pokazuje već opsežna literatura na tom polju. Povrh toga, sudsko tumačenje inherentan je dio primjene prava $i$ ne može se svesti samo na tekstualno, gramatičko tumačenje. Imajući to u vidu, ovaj članak nudi niz argumenata u prilog teoriji o vlasti nad djelom. Naime, iako su moguća različita tumačenja, daljnja primjena teorije o vlasti nad djelom doprinijela bi internoj dosljednosti MKS-a i razvoju dostupnog i predvidljivog korpusa prava pred tim Sudom.

Ključne riječi: oblici kaznene odgovornosti, počinitelji, sudionici, teorija vlasti nad djelom, Međunarodni kazneni sud

* Dr. sc. Maja Munivrana Vajda, docentica Pravnog fakulteta Sveučilišta u Zagrebu, Trg maršala Tita 14, Zagreb 